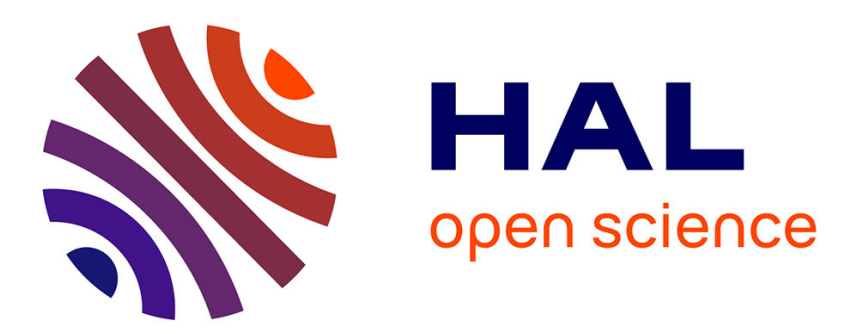

\title{
Help a Teacher in the Conception of a Course by Using Semantic Information
}

Michel Sala, Pierre Pompidor, Danièle Hérin, Gaël Isoird

\section{To cite this version:}

Michel Sala, Pierre Pompidor, Danièle Hérin, Gaël Isoird. Help a Teacher in the Conception of a Course by Using Semantic Information. WI'04: Web Intelligence, Sep 2004, Beijing (China), pp.429432. lirmm-00108791

\section{HAL Id: lirmm-00108791 https://hal-lirmm.ccsd.cnrs.fr/lirmm-00108791}

Submitted on 23 Oct 2006

HAL is a multi-disciplinary open access archive for the deposit and dissemination of scientific research documents, whether they are published or not. The documents may come from teaching and research institutions in France or abroad, or from public or private research centers.
L'archive ouverte pluridisciplinaire HAL, est destinée au dépôt et à la diffusion de documents scientifiques de niveau recherche, publiés ou non, émanant des établissements d'enseignement et de recherche français ou étrangers, des laboratoires publics ou privés. 


\title{
Help a teacher in the Conception of a Course by using Semantic Information
}

\author{
Michel Sala, Pierre Pompidor, Danièle Hérin, Gaël Isoird \\ LIRMM - 161 rue Ada 34392 Montpellier, France \\ \{sala,pompidor,dh, isoird\}@lirmm.fr
}

\begin{abstract}
This paper aims to help a teacher to improve its course by using semantic information. For it, we supply to the teacher a means to evaluate his on-line course with regard to the student browsing.. So, we can reveal various types of problems and propose a referential or a conceptual revision of the course. The learning phases, and so knowledge acquired with by students are improved. Course is modelled by a global ontology and we study the student logs to obtain semantic information about their browsing.
\end{abstract}

\section{Introduction}

In this article, we put at first several strong hypotheses which are the bases of our study. First of all, we suppose that the teacher does not use a learning platform. We take for start point a course already created by the teacher on which students are going to make learning phases. We suppose to have access to the logs of the server where are stored the courses data. We put as well the hypothesis as the global ontology of the course is known what will allow us to make a link between concepts approached on the course and those shown by students. This paper builds on work described in an article which we presented at ITS [1] on the revision and composition of a class course from educational resources on the web. The general principle of our architecture was tested on a problem linked to the maintenance of a web site [2] for the computer editor PC-Soft (www.pcsoft.fr).

This paper is organized in the following way: at first, we are going to present the context in which we work, then we shall describe the stages of the process which allows to make a link between the student browsing and the concepts approached on the course. Then, we shall detail the analysis phase of the connection logs with the student categorization step. Then we shall show the two types of possible revision following met problems. Finally, we shall end summarizing our main contribution and by opening on our perspective intendeds.

\section{Context}

\subsection{Ontology}

As we expressed it in the introduction, we suppose that the global ontology of the course is known. The scientific community has shown interest in the concept of ontologies for representing knowledge as well as making their sharing and their reusing easier. Among various definitions given in the literature, the most frequently quoted is one from Gruber : "An ontology is an explicit specification of a conceptualization, i.e. a description of a part of the "world" in terms of concepts and relations between these concepts " [3]. We call global ontology the general ontology of the course representing any concepts approached on the course as well as the various types of relations which can exist between these concepts (relation of composition, prerequis ...).

In our study, a global ontology is so a graph of concept with relations between these concepts. The figure 1 illustrates a simple example of ontology of a course concerning mathematical operations. We can see among others that the concept of addition is a prerequis in that of subtraction.

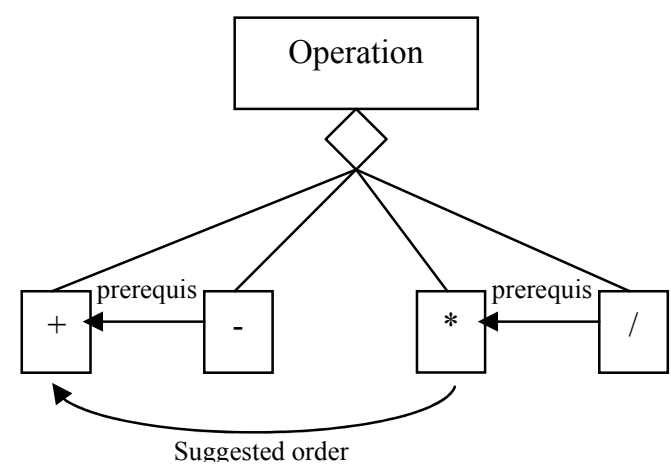

Figure 1 : An example of ontology

At first, by concern of simplicity, we choose a $\mathrm{XML}$ [4] representation to model this global ontology. 
We don't exclude to use more specific languages as DAML[5] or OWL[6] for this modelling in the future.

This extract of XML file representing the following global ontology:

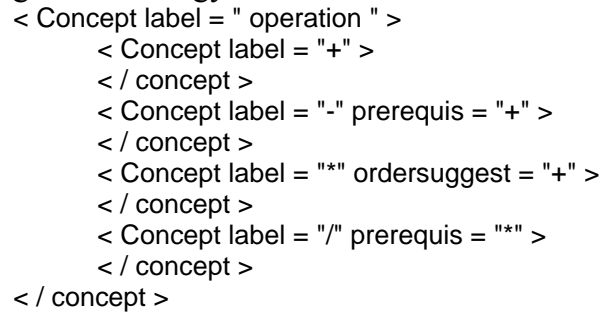

\subsection{Graph of the site}

To be able to analyze the student browsing on the course, we need to know the graph of the site. We stores in a simple file text the tree structure of the site. For every page, we use a couple $\{a, b\}$ or a represent the page URL $b$ links contained in a allowing to reach other URL. Supplementary information is preserved such as compulsory links (login page).

\subsection{The educational materials}

During the course construction, we supposes that the teacher has the possibility of using different educational materials such as written paragraphs, images, videos, links towards the other sites or still bibliographical references. Due to the use of metadata [7][8][9], a precise description of materials and so approached concepts is possible.

\subsection{The Course}

The course is already created, due to the help of metadata describing materials and the global ontology of the course, we can deduct the sequence of concepts approached on the course. A sequence or cursus, is a chain of concept connected with three operators' types:

- Sequence of order: $\mathrm{Ci}->\mathrm{Cj}$, the concept $\mathrm{Ci}$ must be seen before the concept $\mathrm{Cj}$

- Parallel : $\mathrm{Ci} / / \mathrm{Cj}$, the two concepts can be seen at the same time by the student

- Alternative $\mathrm{Ci} ; \mathrm{Cj}$, the student has the choice enters concept $\mathrm{Ci}$ and $\mathrm{Cj}$.

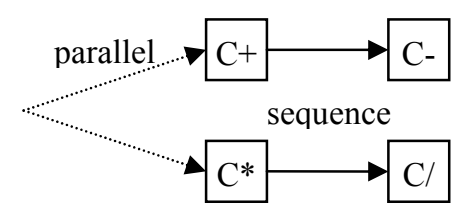

Figure 2 : Example of a sequence

In the example of this sequence (figure 2), the teacher doesn't take into account the order link suggested in the global ontology between the concept of addition and multiplication, he leaves the possibility to the students to view them in parallel.

\subsection{Logs knowledge}

Access to the logs files of the server containing course allows us to know the student browsing on the site and so to see which are the pages visited.

\section{Information search}

\subsection{General architecture}

The figure 3 presents the general architecture of our system. On the top, we can see bases of our system.

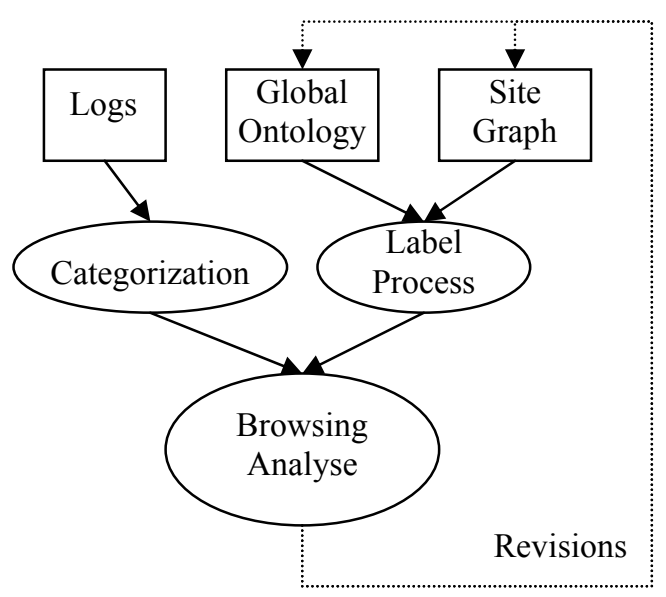

Figure 3 : General architecture

\subsection{Label Process}

This step consists to label global ontology, that is to reference for every concept contained in the global ontology, the URLS which contain educational materials treating to these concepts. So, if we resume our example and we suppose here that there's a page for every approached concept, we obtain a global ontology labelled like this:

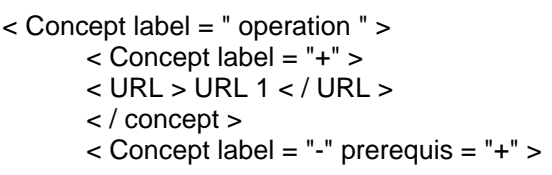




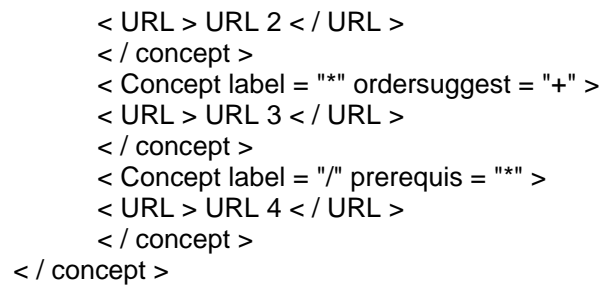

This labelled global ontology is going to allow to make a link between the graph of the site its semantics. This process will allow to know viewed concepts by the users who will have crossed this page

\subsection{Categorization}

Due to the $\operatorname{logs}$ analysis, having made a preprocessing of data, we can create students groups according to browsing similitudes The preprocessing step of data consists in making a cleaning of logs in order to be able to analyze them. By cleaning, we talk about eliminating information contained in the logs which are not useful for us but also to delete the lines of logs not significant such as lines referencing reached pages which during some seconds (where we suppose that the user didn't have the time to read the the page content). . In this article, we do not discuss the ways the categorizations are calculated since projects already exist in this domain such as: [10], [11].

As regards the analysis, we uses data mining techniques with an algorithm of type Apriori to determine the frequent sets of pages and an algorithm of type AprioriAll to extract the frequent sequences [12][13]. Due to this data analysis, we are able in this step to obtain students groups having in common a similar browsing on the site.

\subsection{Analyze the student browsing}

Having analyzed the connection logs and by using global ontology labelled, we can put in report a set of students having a similar browsing with viewed concepts. For it, we select concepts seen by the group in the labelled global ontology and we compare this set of concept with the global ontology and with the sequence. The principal aim is to find possible problems contained in the site as the possibility of seeing a concept before its prerequise or still inaccessible concepts because of the site modelling. In our example, we suppose that a student group crossed pages url 2 url 1 and url 4.

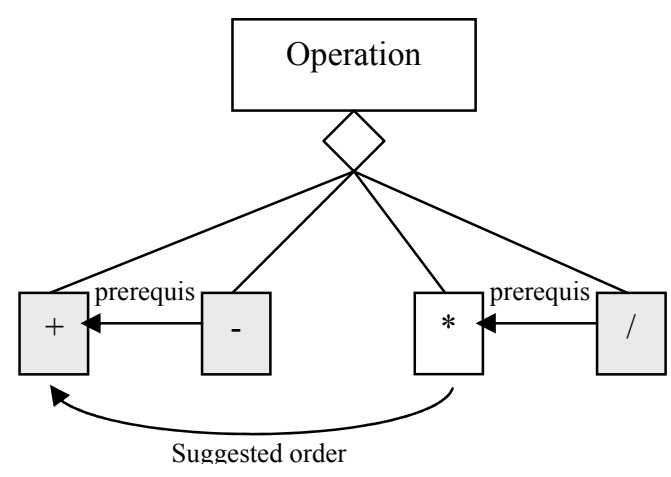

Figure 4 : Concepts selected in the global ontology

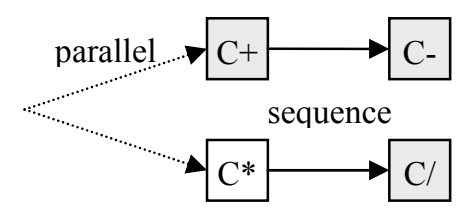

Figure 5 : Concepts selected in the sequence

Due to the labelled global ontology and to the sequence (figure 4 and 5), we can reveal here the fact that students hasn't seen the addition concept and the subtraction concept in the good order because the subtraction was seen before the addition. We can reveal to that students worked on the division concept without having seen multiplication what is in discord with the global ontology of the course. Remarks are going to have returned to the teacher and to the designer of the site to be able to possibly revise the course conception.

\subsection{Revision}

We distinguishe two types of revisions, functional revision and conceptual revision.

Functional revision takes care of physical modelling problems of the pages chains. It is rather intended for the site designer and allows him to know the little visited pages or the erroneous links. This revision aims to mitigate these problems and to reorganize the site structure by moving pages, adding or deleting links.

Conceptual revision is more centred on the semantic and the concepts modelling expressed in the course. It is useful for the professor who is going to know concepts little approached with students on his course and the typical navigation errors with regard to 
the cursus (concept shown before the prerequise ...). The teacher will then be able to wonder about the conception of his cursus. $\mathrm{He}$ can also make modifications at the global ontology level of his course.

These two combined types of revisions will allow one better student browsing and so a better phase of learning.

\section{Conclusion}

In this paper, we presented the bases of our study aiming to help a teacher to improve the course due to obtained semantic information by analyzing the student browsing. For it, we put strong hypotheses such as the possibility of using the connection logs, which the teacher does not use a particular learning platform and which the global ontology of the course is known.

Thanks in the process of labeling the global ontology of the course, and in the analysis of the student browsing on the site, we set up a means allowing to return semantic information about the student navigation. This information allows to make two types of revisions, functional and conceptual which aim to improve the course organization on the site, the student navigation and so their learning phases.

\section{Perspectives}

This work completes the classic tools of analysis Web sites. We have already set up one tools of semantic analysis of the Web site [14]. One of our perspective is to adapt this tools to the e-learning context.

\section{References}

[1] D. Hérin, M. Sala, P. Pompidor, "Evaluing and revising browsing from web resources educational", ITS 2002, Springer-Verlag LNCS, juin 2002, pp 208-218.

[2] M. Sala, P. Pompidor, D. Hérin, "Aid to the semantic maintenance of the web site", IADIS WWW-Internet 03, Algarbe Portugal, November 03, 9 pages

[3] T. Gruber, "A Translation Approach to Portable Ontology Specifications. Knowledge Acquisition", 1993, pp 19-220

[4] www.w3.org/XML

[5] DARPA Agent Markup Language www.daml.org
[6] OWL Web Ontology Language

w3.org/TR/2002/WD-owl-ref-20021112/

[7] http://www.dublincore.org/documents/educationnamespace/

[8] IEEE Learning Technology Standards Committee (LTSSC), Learning Object Metadate (LOM), Draft Document 2001, IEEE P1484.12

[9] http://www.adlnet.org/Scorm/scorm_index.cfm

[10] P. Baudracco, A-L. Beylot, C. Fleury, S. Monnier, M. Becker, "Performance Measurement of the web server, Design of a first model". Research in official Statistics. Volume 1, number 1, 1998

[11] H-K. Choi, O. Limb, "A behavioural Model of Web Traffic". International Conference on network Protocole, 1999

[12] R. Srikant and R. Agrawal, "Mining Sequential Patterns: Generalizations and Performance Improvements". In Proceedings of the 5th International Conference on Extending Database Technology (EDBT'96), Avignon, France, Septembre 1996, pp 3-17

[13] R. Agrawal, R. Srikant, "Fast Algorithms For Associations Rules"

[14] M. Sala, G. Isoird, "Semantic Analysis of a Web Site: a Prototype" IWWOST ICWE2004 Munich July 2004 